\title{
ŞAPTE CORELAȚII ÎNTRE VIOLENȚA INTERPERSONALĂ ȘI PROGRESUL RELIGIEI ORGANIZATE
}

\author{
Marian Gh. SIMION \\ Universitatea Harvard, SUA
}

\begin{abstract}
Rezumat. Fără a se focaliza în mod necesar pe abordarea problematicii originii religiei, acest articol propune de fapt șapte corelații intre violența interpersonală și progresul religiei organizate, sugerând că violența interpersonală a jucat un rol semnificativ in procesul de instituționalizare a credințelor religioase. Deși violența interpersonală nu provoacă neapărat structurarea credinței religioase, aceasta de fapt întărește și oferă soluții modelelor existente de amenințare cu care se confruntă o comunitate, iar împreună conduc la organizarea religiei.

Prima parte a acestui articol (etapele 1-4) analizează psihologia violenței, concentrându-se pe teoriile frustrare - agresiune, rivalitate mimetică, triangulare, geneza țapului ispășitor și vinovăție. A doua parte (etapele 5-6) marchează trecerea de la psihologia personală la psihologia socială și studiază violența în religia primitivă, așa cum se manifestă în procesul ritualizării țapului ispășitor și în geneza sacrificiului. A treia parte (etapa 7) evidențiază complexitatea ritualului, a eticii și a doctrinei în evoluția religiei de la starea primitivă la instituirea religiei organizate.

Cuvinte-cheie: conștiința morală, culpabilitate, doctrină, etică, frustrare agresiune, lider - profet, mimesis, părinte, psihologia copilului, rivalitate, religie, ritual, sacru - profan, sacrificiu, triangulare, țap ispăşitor, violenţă.
\end{abstract}

\footnotetext{
Abstract. Without necessarily focusing on approaching the issue of the origin of religion, this article actually proposes seven correlations between interpersonal violence and the progression of organized religion, suggesting that interpersonal violence has played a significant role in the process of institutionalizing religious beliefs. Although interpersonal violence does not necessarily cause the structuring of religious faith, it actually strengthens and provides solutions to the existing threat patterns faced by the community, which together they lead to the organization of religion.

The first part of this article (stages $1-4)$ surveys the psychology of violence, by focusing on the frustration - aggression theories, mimetic rivalry, triangulation, the genesis of scapegoating and guilt. The second part (stages 5 -6) marks the transition from personal to social psychology and surveys violence in the primitive religion, as manifested in the ritualizing process of the scapegoat, and the genesis of sacrifice. The third part (stage 7) highlights the complexity of the ritual, ethics and doctrine, in the evolution of religion from a primitive state to an advanced organized institution.

Keywords: moral conscience, culpability, doctrine, ethics, frustration - aggression, leader - prophet, mimesis, parent, child psychology, rivalry, religion, ritual, sacred profane, sacrifice, triangulation, scapegoat, violence.
} 


\section{Prezentare generală}

De-a lungul ultimelor două secole, renumiți filozofi, psihologi, sociologi și antropologi precum Émile Durkheim (1969), James Frazer (1996), E. E. Evans - Pritchard (1956), Sigmund Freud (1998), Mircea Eliade (1974, 1987), Max Weber (1977), 1991), Rene Girard (1977, 1979, 1986, 1987, 1996), Henri Hubert și Marcel Mauss (1981), Walter Burkert (1979, 1986, 1996) și alții au încercat să demonstreze originile sociale ale religiei într-un efort deliberat făcut cu scopul de a respinge viziunea comună asupra religiei ca având origini divine. $\mathrm{Cu}$ toate acestea, în demonstrațiile lor, efectele violenței interpersonale asupra progresului religiei organizate au fost oarecum trecute cu vederea. Girard și Burkert sunt probabil singurii cercetători elocvenți care au înțeles rolul și semnificația violenței interpersonale în organizarea credinței. Cu toate acestea, ambii cercetători sunt nepreciși atât în clarificarea legăturii dintre violența interpersonală și organizarea credinței de-a lungul celor trei piloni de bază ai religiei - doctrină, morală și ritual - cât mai ales în explicarea modului în care, în dezvoltarea lor incrementală, acești trei piloni ai religiei organizate au fost stimulați și informați de experiența violenței interpersonale.

Prin urmare, acest articol încearcă să umple acest vid structural.

În prima parte (violență și psihologie), articolul va evidenția patru fundamente psihologice ale conflictului interpersonal, ancorate în prezumţia că instinctele observabile în psihologia copilului reprezintă o constantă a comportamentului uman indiferent de vârstă sau sistem cultural. Prima etapă (conflictul) se focalizează pe psihologia copilului, concentrându-se pe mecanismul frustrare - agresiune ce decurge din experimentul unei competiții dintre doi bebeluşi asupra unui obiect dorit în mod egal de aceștia și pe mecanismul rivalităţii mimetice care apare datorită concurenței. În cea de-a doua etapă (triangularea), conflictul dintre bebelușii concurenți implică triangularea părintelui, care este atras în conflict ca mediator pentru a calma tensiunea. În cea de-a treia etapă (țap ispăşitor), părintele preia controlul asupra conflictului și îi privează pe bebelușii concurenți de obiectul dorit; astfel devenind țapul ispășitor care va absorbi furia bebelușilor concurenți. În cea de-a patra etapă (vinovăția), părintele implementează conștiința emoțională (sau morală) a vinovăţiei și preia pe deplin controlul asupra conflictului.

Cea de a doua parte (violența și religia primitivă) marchează trecerea de la psihologia personală la cea socială. Odată cu progresul în vârstă al bebelușilor concurenți, evaluarea sentimentului culpabilității (împreună cu puterea de a diagnostica pe deplin cauzele conflictului și de a găsi remediul adecvat) este transferată de la părinte la liderul - profet al comunității. Astfel, cea de-a cincea etapă (ritualul) introduce triangularea liminală, prin care puterea de mediere a părintelui este transferată de la părinte la liderul - profet al comunității, prin ritualuri de tranziție și inițiere. În urma acestui transfer de putere de la părinte la liderul - profet, mai multe fenomene noi intră în joc în interesul 
colectiv al grupului. Aceste fenomene noi includ stabilirea unor norme morale prin conștientizarea legăturii dintre culpabilitate și pedeapsă și prin crearea unor narațiuni menite să justifice regulile etice și să le întărească prin puterea ritualului.

Prin urmare, etapa a șasea (sacrificiul) analizează administrarea violenței mimetice de către societate prin procesul de ritualizare a țapului ispășitor și prin geneza actului sacrificial vizibil în religia primitivă. Prin separarea dintre sacru și profan și prin stabilirea regulilor morale privind culpabilitatea și pedeapsa, societatea și-a creat propriul înțeles religios în scopul asigurării stabilității și a supraviețuirii. Odată cu progresul istoric al religiei, țapul ispășitor și sacrificiul au devenit factori decisivi în soluționarea conflictului uman deoarece societatea a separat sacrul de profan prin amestecarea ritualului cu ideea de ordine publică și moralitate, în timp ce finețea doctrinelor a fost codificată în narațiuni sacre concepute pentru a da sens vieții.

A treia parte (violența simbolică, suprastructura teologică și ambivalența structurală) marcată de etapa a șaptea (religia organizată) se concentrează asupra stadiului avansat al standardizării credinței și pe suprastructura teologică prin care sensul vieții este dezvoltat mai departe și sistematizat în doctrine, texte sacre și în standarde morale. În acest context culpabilitatea și pedeapsa sunt definite, interpretate și aplicate prin diferite canoane și legi religioase, iar ritualurile de ispășire și sacrificiu sunt înlocuite de violența simbolică (Figura 1).

\section{Psihologia violenței}

De ce este ființa umană violentă? Adesea considerată ca fiind un „,cocktail nociv compus din gene și mediu” (Moosajee, 2003), psihologia violenței a preocupat orice minte din orice secol și din orice cultură. Ancorată în cele două verbe auxiliare $a$ avea (posesie) și a fi (identitate), psihologia violenței a fost și rămâne îndreptată atât împotriva sinelui (masochism), cât și împotriva celuilalt (sadism).

Deși se crede în general că violența poate fi oprită numai prin violență retributivă, atunci când este înțeleasă și aplicată drept răzbunare - în baza conceptului „ochi pentru ochi” - în mod ironic, această înţelegere stă la baza ciclicalităţii violenței. Aceasta se datorează faptului că, după cum spune Girard (1979, p. 26), „orice om dorește să fie cel care dă ultima lovitură, iar astfel represaliile pot fi urmate de alte represalii fără să se ajungă vreodată la o concluzie." Natura virală a violenței necontrolate este încorporată în trăsătura sa mimetică, ridicând provocări serioase oricărui proces de imunizare împotriva acesteia. De fapt, orice efort de preluare a controlului asupra violenței retributive creează noi condiții în care violența prosperă. În același timp, violența controlată reprezintă singurul fenomen ce validează argumentul ,a lupta împotriva focului cu focul”, deoarece acest tip de violență este mai degrabă rațional în natura sa decât emoțional, iar acesta derivă din fenomenul ,țapul ispășitor”.

Adoptând o perspectivă evolutivă, care, în mod exclusiv, supune umanitatea instinctului ucigaș - instinct tipic regnului animal și a supraviețuirii celui mai 


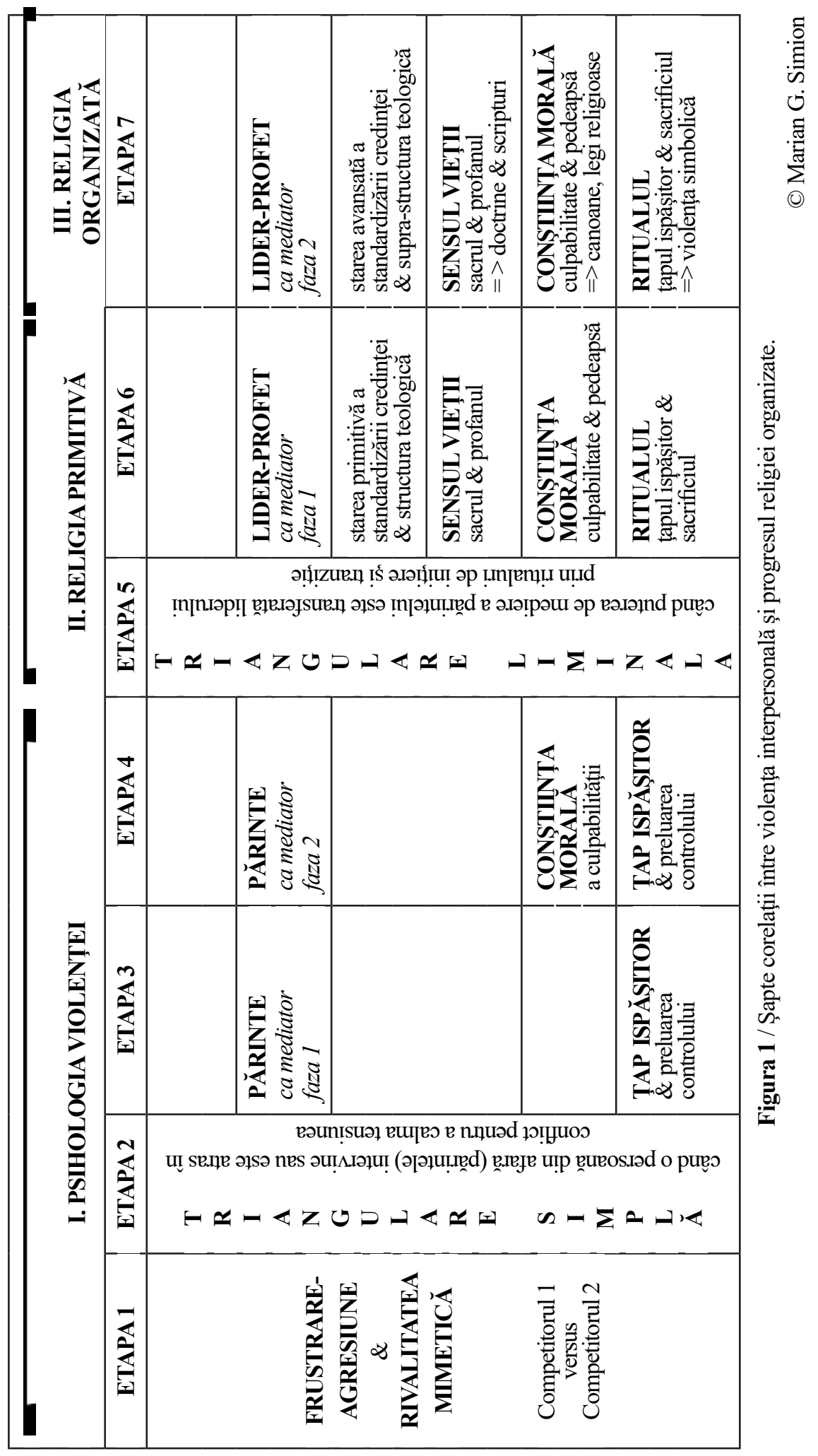


adaptat - diverși cercetători consideră că agresivitatea umană este o trăsătură intrinsecă a regnului animal. De exemplu, Konrad Lorenz (laureat al Premiului Nobel) a subliniat că agresivitatea din cadrul regnului animal îndeplinește trei funcții: (1) echilibrul distribuției speciilor, (2) selectarea celui mai puternic și (3) protejarea puilor.

În cadrul acestor trei funcții, Lorenz mai notează şi anomalii precum o specie de pește care, dacă este lipsit de dușmanii săi naturali, cum ar fi rivalii masculi cu care își dispută în mod obişnuit drepturile teritoriale, acesta își îndreaptă agresiunea împotriva membrilor propriei familii pe care îi distruge (Girard, 1979, p. 2; Lorenz, 1966). Cu toate acestea, încătușați de determinism genetic și de teoriile selecției naturale, majoritatea oamenilor de știință moderni au evitat aprofundarea dimensiunii spirituale a violenței. În schimb au continuat argumentele pe baza întrebării dacă violența are o structură genetică sau este un comportament dobândit, adică dacă este înnăscută sau cauzată de mediul geo-cultural. În istoria umanității, se poate observa cum religia a încercat și chiar a reușit să croșeteze un mecanism fiabil de control împotriva autodistrugerii umanității - mecanism construit din însăși esenţa procesului în sine - și care a diferențiat între violența necontrolată și cea controlată.

\section{Frustrare - Agresiune și rivalitate mimetică}

Dollard și colaB. (1939) în lucrarea lor, Frustration and Aggression, au demonstrat că eșecul suferit în urma inabilității de a obține un obiect dorit în mod reciproc de doi concurenți duce la agresiunea unuia împotriva celuilalt; astfel dând naștere unui ciclu de rivalitate și violență. Mai târziu, Denzler, Förster și Liberman (2009, p. 90-100) au demonstrat că odată cu împlinirea unui deziderat agresivitatea scade. Acest lucru se datorează faptului că, așa cum demonstrează Girard (1979), dorința umană este în mod inerent mimetică, în sensul că, prin actul imitării, o persoană împrumută dorinţa de la o altă persoană, astfel dând naștere unui ciclu de rivalitate care duce la violență. Mai mult, Girard a demonstrat faptul că dacă violența rămâne nesatisfăcută, violența caută și găsește întotdeauna o victimă surogat (țap ispăşitor) care să absoarbă violența și care să fie sacrificată pur și simplu pentru că „sacrificiul are rolul de a proteja întreaga comunitate împotriva propriei violențe" (Girard, 1979, p. 8). Conform teoriei frustrare - agresiune (Dollard et al. 1939), când doi concurenți își încep competiția pe un obiect dorit în mod reciproc, primul concurent (făptuitorul) obține obiectul dorit în mod indirect prin rănirea celui de-al doilea concurent. Drept urmare, al doilea concurent devine victimă, iar primul instinct al acestuia este să riposteze în autoapărare. Din cauza violenței victimei efectuate ca represalii, făptuitorul este gata să lovească pentru a doua oară, creând astfel un ciclu de violență care poate conduce la distrugerea unuia dintre concurenți.

Declanșatorul actului frustrare - agresiune este însăși dorința de posesie, iar după cum demonstrează Girard, dorința umană este mimetică. Cu alte cuvinte, 
o persoană împrumută dorința de la o altă persoană; stimulând astfel dorința celuilalt de a obține același obiect. În al doilea rând, dorința împrumutată provoacă rivalitate între cei doi concurenți, ceea ce poate duce la violență. Prin urmare, pentru a evita un ciclu nesfârșit de violență care în mod cert va conduce la distrugerea unuia dintre concurenți, aceștia (concurenții) își redirecționează violența asupra unei părți terțe care devine țap ispăşitor. Acest mecanism a fost descris cu acuratețe de René Girard ca fiind universal, prin analiza transversală a miturilor și ritualurilor celor mai larg răspândite pe care le-a selectat în manieră aleatorie din diferite timpuri și zone geografice (Girard, 1977, 1979, 1986, 1987, 1996, 2001).

\section{Mimetica experimentală și triangularea simplă}

Mecanismul mimetic al violenței poate fi explicat prin următorul experiment: într-o cameră goală așezăm doi bebeluși de vârstă egală. Inițial, bebelușii sunt mulțumiți. Mai târziu, o jucărie este plasată între cei doi bebeluși. În urma acestui eveniment, bebeluşii devin curioși și fiecare începe să își dorească jucăria. Un bebeluș ajunge mai întâi la jucărie și o apucă. Văzând acest lucru, celălalt bebeluș vine și ia jucăria de la primul bebeluş. Primul bebeluş devine frustrat și își recuperează jucăria, declanşând furia celuilalt bebeluş (etapa 1). În timpul acestui proces, părintele devine conștient că fără intervenția acestuia, bebelușii se vor răni reciproc. În consecință, părintele este obligat să intervină, caz în care părintele este triangulat în conflictul dintre cei doi bebeluși (etapa 2) în sensul că problema dintre cei doi bebeluși devine și problema părintelui.

\section{Două ipoteze valide}

Odată cu triangularea părintelui, conflictul fie se încheie, fie continuă să se dezvolte în funcție de acțiunea părintelui. Așadar, decizia părintelui generează două conditii pentru conflict.

În primul rând, dacă părintele elimină obiectul dorit, conflictul se încheie în sensul că obiectul dorit devine un țap ispășitor, iar eliminarea acestuia eliberează, absoarbe și deraiază furia bebelușilor (etapa 3), întrucât niciunul dintre ei nu poate intra în posesia obiectului.

În al doilea rând, putem adopta ipoteza că părintele nu elimină obiectul dorit (jucăria) ci îl oferă drept recompensă unuia dintre bebeluși, iar pe cel de-al doilea îl aşază într-un pătuţ, în spatele gratiilor. În acest caz, mai multe efecte încep să prindă contur. În primul rând părintele nu mai rămâne un terț independent în cadrul rivalității dintre bebeluși, deoarece acesta se transformă în concurent prin aderarea la cauza unuia dintre bebeluși în defavoarea celuilalt. Într-un cadru natural, un astfel de comportament al părintelui, deși fezabil și plauzibil, nu numai că nu reușește să încheie conflictul dintre bebeluși, cât mai ales creează și daune emoționale celor doi concurenți. Prin abandonarea rolului de a rămâne un terț independent, părintele deraiază de la instinctul natural al regnului animal și afișează un comportament 
uman deviant; contrazicând însuși instinctul de „protejare a puilor” notat de Konrad Lorenz în lumea animală. Mai mult, ca urmare a eșecului părintelui de a rămâne un terț independent, bebelușii vor începe să-și construiască identitatea în raport cu sentimentele construite unul față de celălalt; sentimente definite și controlate de competiția asupra obiectului dorit. În consecință, un bebeluș începe să se vadă pe sine ca învingător (superior), în timp ce celălalt începe să se vadă pe sine ca învins (inferior.) Mai mult, deoarece bebelușul învins încă mai reprezintă o amenințare potențială pentru bebelușul învingător, bebelușul învingător începe să-și construiască un arsenal de apărare împotriva oricărei eventuale agresiuni iniţiate de bebelușul învins. În același timp, bebelușul învins se simte din ce în ce mai înstrăinat și lipsit de drepturile care crede că i se cuvin; construind astfel resentimente puternice împotriva celorlalți oameni și dorințe de a-și restabili integritatea. În decursul timpului, cei doi bebeluși își construiesc identitatea în temeiul resentimentelor reciproce, punând astfel bazele unei culturi a conflictului existențial.

Așadar, după cum se poate concluziona, dacă părintele îndepărtează obiectul dorit, atunci obiectul în sine ,„̂și asumă vinovăția” pentru conflictul generat și devine un țap ispășitor eficient, punând capăt conflictului. În schimb, dacă părintele nu reușește să rămână un terț independent, atunci starea de vinovăție este atribuită concurentului învins, iar conflictul continuă (etapa 4). Mai mult, acest experiment dezvăluie procesul germinativ al principalelor teorii ale violenței colective: frustrareagresiune (când se introduce obiectul dorit), instrăinare - privare (când părintele nu rămâne un terț independent) și violența ca și comportament dobândit (când cei doi bebeluși își construiesc identitatea pe resentimente și frică de pierdere).

\section{Vinovăţia ca spațiu de ciocnire dintre psihologie şi religie}

Este important de menționat că intervenția părintelui - indiferent de natura acesteia - conduce și la stabilirea conștiinței morale a vinovăției sau culpabilității. Presupunând că părintele îndepărtează jucăria, un conflict inevitabil apare între părinte și cei doi bebeluși. În timpul derulării acestui conflict nou (și al conflictelor care succed sub aceeași paradigmă), părintele își va asuma dominația asupra situației apelând la sentimentul de culpabilitate. Sentimentul de culpabilitate este stimulat și dezvoltat fie printr-un apel la intervenția unei amenințări externe imaginare (de exemplu, frica de întuneric, frica de Babau), printr-un apel la propriile vulnerabilități ale părintelui (prin care acesta joacă rolul de victimă și se preface că plânge), sau printr-un apel la ego-ul și personalitatea bebeluşilor aflate în plină dezvoltare, apel prin care bebelușii devin conștienți de importanța reputației personale. Prin urmare, strategii precum protejarea reputației, teama de amenințări imaginare și empatia față de părinte stimulează creșterea și solidificarea conștiinței morale a culpabilității ca inhibitor al agresiunii. Asocierea dintre o faptă negativă și intervenția consecventă a unor forțe externe înspăimântătoare reprezintă locul de întâlnire dintre psihologie și religie. Frica de întuneric devine asociată cu răul existențial; mila și teama față de părinte devin asociate cu 
dragostea și respectul față de autoritatea spirituală; iar reputația personală devine asociată cu conformitatea față de principiile religioase.

\section{Violența și religia primitivă}

Legătura dintre psihologia violenței și religia primitivă a câștigat o atenție sporită în ultimele secole.

Numeroase studii eminente și-au orientat atenția către motive și teme cum ar fi răul existențial, sacrificiul, țapul ispășitor, crima primordială, martiriul, teroarea, mimetica, mitul, ritualul și legăturile stabilite între religie și biologie, psihologie și etologie etc., (Burkert, 1979, 1986, 1996; Eliade, 1987; Girard, 1986, 1987, 2001; Juergensmeyer, Kitts \& Jerryson, 2013; Lorenz, 1966; Nayak, 2000). Conform arheologiei, unele dintre aceste motive religioase există de peste 180000 de ani, deoarece amprentele acestora pot fi documentate în timp până în perioada glaciară. În cadrul acestor documentări, mostrele de comportament uman ce au fost identificate au demonstrat cum ființa umană a manifestat o conștientizare morală evidentă a ceea ce este drept și nedrept, conștientizări pe care le-a asociat cu binele și răul, în timp ce cultul eroului, gestionarea crizelor naturale și ritualurile de supraviețuire și fertilitate au devenit evidente în manifestările de magie și fetișism, în tabuuri și totemism, în cultul strămoșilor, în divinitățile tribale și așa mai departe (Sparks, 2013). Printre numeroasele obiecte de analiză, mostrele de mimetică, ritual, sacrificiu și țap ispășitor apar ca forme universale de comportament care stau nu numai la baza instituționalizării religiei cât și la baza dezvoltării civilizaţiei umane. După cum este evident, aceste mostre comportamentale au contribuit la dezvoltarea religiei în sensul că au influențat structurarea acesteia în maniera în care religia și-a construit propriile narațiuni spirituale, a impus modele de comportament și a ritualizat sensul vieții; oferind fiecărui individ și generație un scop de a trăi în pelerinajul dintre naștere, moarte și viața de apoi.

\section{Triangularea liminală: de la personal la colectiv}

În ceea ce privește psihologia evolutivă, transferul atitudinii emoționale față de violență din mediul particular al îngrijirii copilului în mediul public al societăţii umane rămâne ancorat în psihologia copilului. Datorită eficacității lor, mecanismul țapului ispășitor și conștiința morală a culpabilității dezvoltată de părinte în mediul privat au fost translate în spațiul public unde au condus la fondarea sacrificiului religios. Pentru societatea primitivă, culpabilitatea și sacrificiul au adus nu numai stabilitate socială, ci au creat și o separare a spațiului public între „văzut” (profan) și „nevăzut” (sacru) (Eliade, 1987, p. 14-15).

Mai mult, pentru menținerea continuității dintre mediul privat și spațiul public, în societățile primitive, tranziția de la copilărie la maturitate este marcată de rituri de trecere; rituri la care întreaga comunitate trebuie să asiste și să participe. Este un concept similar societății moderne care atribuie vârsta de 18 ani ca fiind 
vârsta la care copilul devine adult, iar ca atare părintele nu mai este responsabil în fața societății pentru comportamentul lui.

Prin urmare, în tranziția de la copilărie la maturitate (etapa 5), rolul protector și pedagogic jucat de părinte în cadrul rivalităţii mimetice este transferat liderului - profet - un specialist spiritual recunoscut ca povestitor, vindecător și intermediar mistic Fisher (2008, p. 49-55) - căruia tânărul adult i se încredințează social, în timp ce liderul - profet devine părinte surogat (abba, bhikkhu, bătrân, tată, părinte, pastor, naș, nașă, imam, maică, pujari, rabin, rōshi, șaman, țar - batushka și așa mai departe) și al cărui rol colectiv devine acela de a învăţa, de a îndruma, de a pedepsi și proteja pe noul adult împotriva oricărui pericol venit din interiorul sau din exteriorul comunității.

Ca atare, conștiința morală a culpabilității ce a luat naștere în urma calamității emoționale a rivalității mimetice primitive evoluează de la un sentiment interior al faptelor greșite (fapte care inițial au fost evaluate și judecate de părinte și care au generat remușcări emoționale) la o recunoaștere exterioară a transgresiunii (acestea fiind acum evaluate și judecate de liderulprofet). De acum înainte orice transgresiune implică fie compensarea materială a victimei, fie pedeapsa fizică exercitată din partea și în numele comunității. $\mathrm{Cu}$ alte cuvinte, în timp ce prima percepție a vinovăţiei reprezintă o experiență psihologică interioară a sinelui ( a te simți vinovat), cea de-a doua percepție devine o problemă a comunității ( fi vinovat). Această tranziție este probabil cel mai bine explicată de Burkert (1996, p. 102-128), când analizează rolul ,vinovăției și cauzalității”, în cadrul înțelegerii sale cu privire la „creaţia sacrului”. Întrun sens similar, în timp ce în „Complexul Oedip”, Sigmund Freud a prezentat culpabilitatea drept un sentiment de remușcare generat de o crimă preistorică și care a dus la stabilirea religiei totemice (Pals, 2006, p. 65-69), pentru Burkert, vinovăţia are o valoare juridică ce a favorizat stabilirea legii.

\section{Instituționalizarea unui mecanism de rezolvare a problemelor}

Mecanismul de rezolvare a conflictului identificat în mediul privat, în contextul îngrijirii copilului, este translat în spațiul public și devine parte din viaţa socială; fiind implementat prin puterea ritualului. De ce prin ritual? Pentru că, așa cum a afirmat Burkert (1979, p. 35), ,ritualul este ceva ce oamenii fac". Dincolo de o astfel de simplificare excesivă, Burkert (1979) a explicat că:

„ritual este ceva atavic, compulsiv, fără sens, în cel mai bun caz circumstanțial și de prisos, dar în același timp ceva sacru și misterios. (p. 35).

De ce sunt ritualurile puternice? După cum a remarcat Fisher (2008), ritualurile sunt puternice, deoarece acestea

„adesea scot oamenii din conștiința cotidiană și le conștientizează prezența sacrului. În astfel de stări modificate, participanții pot experimenta o conștiință de grup sporită care leagă puternic indivizii împreună ca o comunitate" (p. 56). 
În ceea ce privește procesul în care liderul - profet folosește puterea ritualului pentru a prelua controlul asupra conflictului, Burkert (1996, p. 103) îl descrie ca fiind dependent de patru etape transformatoare: (1) apariţia răului, (2) intervenția liderului - profet ca mediator, (3) diagnosticarea cauzei ascunse și (4) aplicarea ispășirii corespunzătoare.

Astfel, observăm că tocmai această secvență rămâne la baza procesului de instituţionalizare a religiei, deoarece orice instituție nu a reprezentat decât o soluție generală la o problemă colectivă. După cum spune Burkert (1996):

„ritualurile și instituțiile religioase păgâne au și mai multe șanse să iasă din dezastru și să fie întărite în mod decisiv de ritualuri, deoarece evenimentul dezastruos este interpretat şi vindecat prin referiri la vinovăţia religioasă, cu ajutorul mediatorilor (liderul - profet) care ulterior devin activi în numele cultului” (p. 113).

În acest sens, grupul depinde tot atât de mult de liderul - profet pentru a-i oferi stabilitate, cât și liderul - profet depinde de grup pentru a-și consolida autoritatea în faţa grupului. Cu toate acestea, în timpul acestui proces, liderul profet preia controlul deplin nu numai asupra direcției disputei, ci și asupra comportamentului general al grupului, care acum este obligat să se conformeze unui set de reguli noi menite să crească puterea liderului - profet. Tocmai de aceea, pentru Burkert (1996):

„rolul mediatorilor merită o atenție specială: liderul - profet, oracolele, șamanii, vracii, rabinii; cu alte cuvinte, persoanele care ş̦tiu mai multe' și prin urmare, pot ajuta impotriva tuturor tipurilor de rău prezent, reparând tot ce a mers prost. Toate acestea sunt extrem de necesare, deoarece în experiența practică cauza malefică este ascunsă, indiferent cât de evidentă aceasta va putea apărea în narațiunile de prevenire compuse ulterior evenimentului" (p. 116).

În interpretarea „lucrurilor ascunse”, liderul - profet creează o „poveste” pe care o impune ca ,adevăr universal”, prin puterea ispăşitorului şi a sacrificiului - două fenomene creditate cu puterea declanșării procesului de standardizare a comportamentului religios (Girard, 1987, p. 3-131). Astfel, mecanismul de rezolvare a problemelor devine justificat prin narațiuni emergente care își ating claritatea secvențială doar în etapele ulterioare. După cum Burkert (1996) explică acest proces,

„tiparul comportamental evoluează cu uşurință într-o narațiune. Însăşi simpla întrebare „de ce?” necesită o poveste. Când oamenii se confruntă cu un comportament ciudat, ei spun: ,Spune-mi de ce faci asta?' Sensul este creat prin găsirea unei modalități de a vorbi coerent despre evenimente. Un rezultat poate deveni însăşi povestea tipică de avertizare. $\mathrm{Cu}$ toate acestea, narațiunea inversează secvența trăită în viața practică: începe cu greșeala în sine sau greșeala inițială, fie că este o încălcare a unui tabu, fie o încălcare a legii, a ordinii sau a moralității, fie doar o acțiune neprevăzută și imprudentă; explică modul în care, în consecință, răul se manifestă și continuă să descrie cum a fost în cele din 
urmă depăşită prin mijloacele adecvate. Narațiunile permit variații care de regulă includ catastrofa în partea finală, însă în viața practică ne agățăm cu optimism de posibilitatea depăşirii dezastrului” (p. 112-113).

Dintr-o perspectivă evolutivă, fenomenele de țap ispășitor și de sacrificiu au fost considerate unele dintre cele mai primitive instrumente de performanță ritualică (Simion, 2017, p. 2). În timp ce fenomenul țapului ispăşitor poate fi privit ca un comportament inferior și ca un instinct primar - întrucât, potrivit lui Lorenz (1966, p. 51, 175), acesta se regăsește și în lumea animală - ispășitorul precede sau chiar condiționează executarea sacrificiului.

În schimb, sacrificiul nu este doar un comportament mai evoluat decât ispășitorul în virtutea faptului că este limitat la natura umană, ci este și un comportament superior în măsura în care organizează contingențele sinelui prin linii spirituale. Furia, care este redirecționată împotriva unei părți terțe inocente și incapabile să riposteze (ispăşitorul), este controlată prin sacrificiu, iar în același timp, sacrificiul devine controlat de ispăşitor, creând astfel o relaţie de mutualitate și interdependență.

\section{Țapul ispăşitor religios}

Societățile primitive au înțeles că violența colectivă este un ciclu nelimitat de vătămare - răzbunare care nu poate duce decât la pierderi reciproce, distrugere și moarte. În același timp, la fel ca în psihologia copilului, primitivii au înțeles că ciclul violenței colective poate fi perturbat și evitat prin trucuri magice (Frazer, 1996, p. 15-45) și prin performanțe mimetice teatrale, similare celor folosite în calmarea copiilor. Datorită eficienței lor, astfel de trucuri magice și performanțe teatrale imitative au fost repetate până la punctul în care acestea au evoluat în ritualuri de sacrificiu. În acest sens, violența săvârșită împotriva unui obiect, a unui animal sau împotriva unei alte ființe umane lipsită de capacitatea de a riposta (Frazer, 1996, p. 693-703) a fost curând percepută ca fiind ,nimic altceva decât o exercitare regulată a ,violenței bune"” (Girard, 1979, p. 37).

Prin crearea de noi sensuri și de noi narațiuni spirituale, s-a ajuns la construirea unei suprastructuri teologice în jurul ritualurilor generate de efectele țapului ispăşitor. Accentul suprastructurii teologice a fost pus pe eficacitate, deoarece narațiunea trebuia să fie pliată rezultatelor empirice de succes. Țapul ispăşitor a devenit epicentrul analizei și a fost încărcat cu puteri duale, contrastante și contradictorii. Ispășitorul este pur și contaminat, curat și murdar, atrăgător și respingător, frumos și urât, bun și rău.

Deoarece țapul ispăşitor urmează să fie distrus, comunitatea trebuie să evite contactul cu o astfel de posibilă victimă. Mai mult, orice violență împotriva viitoarei victime în afara cadrului ritualic implica un sentiment profund de contaminare pentru comunitate. (Acest proces este similar cu atitudinea societăţii moderne visà-vis de pedeapsa capitală, prin care comunitatea este, prin autoritatea sa legală, cea 
care ucide un criminal, astfel încât familia sau clanul victimei să nu fie contaminate de spiritul crimei și al răzbunării.) Țapul ispășitor poate fi real, cum ar fi un obiect de preț, un animal indispensabil sau o ființă umană pe care grupul însuşi refuză să o accepte; un străin sau un membru deviant al comunităţii, cineva considerat ca fiind blestemat din cauza unui defect fizic sau a unei boli care generează frica de contaminare. Țapul ispășitor poate fi de asemenea metaforic, cum ar fi o entitate invizibilă (Satana), un concept sau un gând malefic, un obiect nesemnificativ, un demon sau însuşi răul existențial (Girard, 1986).

Disonanţa cognitivă de a reorienta vina sau represaliile către o victimă mai slabă rămâne, după cum am văzut, un fenomen filogenetic remarcat în lumea animală şi depășește raționalitatea umană. După cum a remarcat Lorenz (1966) în urma studierii animalelor, comportamentul acestora este determinat doar de conservarea speciei, iar „redirecționarea atacului este cel mai ingenios expedient al evoluției pentru a ghida agresiunea pe canale inofensive" și că aceasta derivă din procesul comportamental al animalului de:

„test - eroare, sau mai exact din încercarea urmată de succes, în sensul că acesta (animalul) adesea încearcă mai multe modalități posibile pentru a rezolva aceiași problemă și le folosesc pe toate acestea pentru a avea succes sigur prin soluții duble și triple (p. 54).

În sfera umană, în lumina acestei multiplicități de încercări pentru rezolvarea unei probleme, țapul ispășitor religios a fost practicat nu numai în mod deschis, ci și în mod ascuns printr-o generozitate decepționantă ce implică posibilitatea contaminării. Pe plan intern, ideea de contaminare a ispășitorului a eliminat posibilitatea ca țapul ispășitor în sine să devină sau să rămână un obiect dorit de concurenții interni. Pe plan extern, contaminarea ispăşitorului a contribuit la transferul sau trimiterea răului departe de comunitate. În sens istoric, contaminarea țapului ispășitor a fost atât simbolică (deoarece conținea răul existențial în sine), cât și reală (deoarece darul în sine adesea conținea narcotice sau otravă.) De exemplu, în Orientul Mijlociu antic, în timpul ritualului evreiesc Yom Kippur al Ispăşirii, Marele Preot sacrifica doi țapi: unul ca jertfă pentru Iehova, iar al doilea era trimis în pustie, ducând cu el toate păcatele tribului departe de comunitate (Lv 16, p. 18-22). Mai mult, într-un sens pragmatic, „trimiterea” țapului ispășitor în pustie a reprezentat atât un dar simbolic făcut forțelor amenințătoare, cât și un dar înșelător, pentru că oricine ar fi putut beneficia de acesta în pustie (fiare sălbatice sau triburi rivale) nu făcea decât să se contamineze de păcatele evreilor. Prin primirea unui astfel de „cadou”, fiarele sălbatice sau rivalii primeau o satisfacție de moment, creând în cele din urmă posibilitatea renunțării atacului împotriva comunității evreiești care le-a dăruit acel țap. În același mod, în contextul ritualului Ašhella efectuat în timpul războiului de către hitiți, aceștia foloseau tactica trimiterii unei femei frumoase, a unui berbec și a unor pâini, către tabăra inamicului cu scopul de a transfera răul (probabil derivat din competiția soldaților pentru atenția femeii frumoase și pentru mâncare) departe de propria lor comunitate (Westbrook \& Lewis, 2008: 417-422). 
Mai mult, în timp de război, cretanii practicau drogarea unui taur pe care îl trimiteau spre tabăra inamicului sub formă de dar izbăvitor. Taurul drogat, odată sacrificat și consumat de inamici, intoxica inamicii și astfel cretanii câștigau războiul împotriva inamicilor prin intermediul unui dar decepționant (Burkert, 1979, p. 59-60).

Înșelăciunea practicată prin intermediul izbăvitorului a jucat un rol dublu. A înșelat atât pe dătător, cât și pe primitor, deoarece acest obiect valoros nu a fost niciodată oferit din spirit de generozitate, ci din spirit de sacrificiu făcut cu scopul ispăşirii de păcate, pentru vindecare socială și pentru purificare spirituală. Logica a implicat plasarea simbolică a amenințării și a răului din comunitate în obiectul de sacrificiu (darul în sine), iar prin intermediul acestuia răul și amenințarea au fost transportate departe de grup tot în manieră simbolică. De exemplu, Douglas (1995, p. 31-48) a identificat o practică medievală larg răspândită cunoscută drept „mâncatul păcatelor”. Prin această practică numeroase produse alimentare gustoase erau contaminate spiritual după care erau oferite drept pomană. În măsura în care o practică din satul meu natal din Carpaţi poate fi considerată drept dovadă documentară, pomana efectuată în timpul unei înmormântări nu îndeplinește neapărat funcții filantropice. Mai degrabă, aceasta servește ca vehicul pentru a transfera păcatele neexpiate ale mortului înapoi către cei vii întrucât, odată cu gustarea din alimentele primite drept pomană, primitorii devin obligați să-și răscumpere păcatele preluate de la mort, prin diferite acte de penitență și ritualuri de purificare. În momentul în care cei vii primesc un dar de la familia mortului - în special coliva care simbolizează atât comunitatea precum și corpul mortului - primitorul se contaminează de fapt cu păcatele neexpiate ale mortului; caz în care acum va trebui să efectueze acte de penitență pentru auto-curățire spirituală, pentru a scăpa de păcatele primite din mort, în timp ce mortul se eliberează de păcatele neexpiate în timpul vieții. Evident, toate aceste metode construite în jurul utilizării strategice a țapului ispășitor au fost concepute pentru a pune capăt violenței generate de sărăcie și de a o alunga din comunitate.

\section{Ritualul sacrificiului și sistemul juridic}

Odată cu sacrificarea țapului ispășitor, relația violentă dintre oameni este controlată din ce în ce mai mult prin acțiunea simbolică a lider - profetului, ceea ce duce la recunoașterea acestuia ca fiind posesorul unor abilități superioare celorlalți. În cadrul acestei noi poziții de putere, lider - profetul nu este doar „un simplu individ charismatic, care în virtutea misiunii sale proclamă o doctrină religioasă sau o poruncă divină” (Weber, 1977, p. 253), ci și cineva care „revendică obediența celorlalți drept datorie etică" (Weber, 1977, p. 263), stabilind astfel noi reguli sociale fie ca fondator, fie ca reformator al unei religii. Prin urmare, lider - profetul (re)definește atât interacțiunea dintre membrii grupului, precum și interacțiunea dintre grupuri în scopul de a oferi „o viziune unificată a lumii derivată dintr-o atitudine conștient integrată și semnificativă față de viață" (Weber, 1977, p. 266). 
Această atitudine față de viață se bazează pe o structură de putere concepută în scopul conducerii grupului spre mântuire, în timp ce „echilibrează vinovăţia și meritul acțiunilor individuale ale unei persoane printr-o contabilitate foarte precisă și determină soarta religioasă a acesteia în funcție de rezultatul acestei contabilități” (Weber, 1977, p. 271). Ceremonia de sacrificiu în sine este și o sursă de acumulare a puterii sociale, deoarece implică un tip de comportament colectiv rezervat doar pentru ocazii speciale, construind astfel o structură bazată pe simboluri și reguli ritualice, așa cum este revelat de dezvoltările timpurii ale brahmanismului (Nayak, 2000, p. 66-70).

$\mathrm{Cu}$ toate acestea, odată cu dezvoltarea societății umane, sacrificiul este înlocuit în mod treptat de sistemul juridic, atât în cadrul procesului de instituționalizare religioasă, cât și ca un efort secular paralel. Astfel, legislația a eliminat necesitatea sacrificiului, deoarece această autoritate terță (care nu este contaminată de dispută) devine chiar sistemul penal definit de legile universal valabile menite să ofere o pedeapsă echitabilă. Diverși antropologi precum Lienhardt (2003), Turner (1981), Pritchard (1956) și alții au demonstrat deja că acțiunea rituală este dominantă în societățile lipsite de un sistem judiciar demn de încredere, deoarece ,ritualul în general și ritualurile sacrificiului în special, asumă roluri esențiale în societăţile ce nu dispun de un sistem judiciar ferm" (Girard, 1979, p. 18).

Procesul legislativ elimină, de asemenea, necesitatea unui ritual de sacrificiu, deoarece după cum afirmă Girard (1979)

„funcția sistemului judiciar este ... mai preocupată de securitatea generală ... o diferență decisivă între omul primitiv și cel civilizat fiind revelată de incapacitatea generală a celui dintâi de a identifica vinovatul și de a adera la principiul culpabilității” (p. 22).

$\mathrm{Cu}$ alte cuvinte, răzbunarea nu se auto-perpetuează, deoarece rolul preventiv pe care îl joacă sacrificiul se traduce acum în retribuție judiciară, iar ,,autoritatea judiciară nu este îndatorată nimănui. Astfel este la dispoziția tuturor și este respectată universal" (Girard, 1979, p. 23).

Odată cu dezvoltarea procesului juridic interesul pentru sacrificiu scade dramatic în societate în general. Cu toate acestea, sistemul juridic nu reușește să înlocuiască complet sacrificiul, deoarece sacrificiul își recapătă dominanța în situaţiile în care sistemul juridic este fie ineficient, fie nu mai este recunoscut ca parte terță neutră. Un alt motiv mult mai profund ce justifică supraviețuirea ritualului chiar și atunci când sistemul juridic funcționează și este bine înrădăcinat în ordinea socială - reiese din aderarea completă a ritualului la un comportament ocazional, distinctiv și inerent transcendental (ceva la care sistemul juridic aderă doar parţial), iar acesta este vizibil în practica și administrarea jurământului. 
După cum dovedește Girard (1979), această calitate transcendentală a ritualului demonstrează că

„oamenii pot renunța la propria violență mult mai eficient dacă consideră procesul nu ca pe ceva ce emană din interiorul lor, ci ca pe o necesitate impusă din exterior, un decret divin al cărui cea mai mică încălcare invocă pedepse teribile" (p. 14).

Prin urmare, în cadrul contemporan al competiției interumane, ritualul nu înlocuiește legea, ci o completează în timpul unor ocazii speciale cum ar fi în timpul ceremoniilor politice sau al tranzițiilor. În concluzie, după cum remarcă Girard $(1979$, p. 25), răzbunarea, sacrificiul și legea împărtășesc o identitate fundamentală comună în sensul că acestea, „tind să adopte aceleaşi tipuri de răspuns violent în perioade de criză". Chiar și pentru societatea contemporană, practicile ritualice sunt re-accentuate, iar puterea acestora este restabilită la fiecare calamitate cu care se confruntă un grup. Ritualul uitat este atât o cauză, cât și o soluție pentru bolile cu care se confruntă comunitatea, iar odată ce ritualul este săvârșit, calamitatea încetează (Burkert, 1996, p. 107-108).

\section{Definirea sensului vieții: ritualul între sacru și profan}

Odată cu progresul religiei, cu fiecare intervenție ritualică în cadrul unei dispute, liderul - profet are un țel dublu și anume soluţionarea disputei și consolidarea propriei autorități. Mai mult, în acest proces, liderul - profet definește sensul vieții prin intermediul unei narațiuni care este ambiguă în mod intenționat și prin care se pun bazele unui mit sacru. $\mathrm{Cu}$ alte cuvinte, liderul - profet spune o poveste care încearcă să răspundă la întrebările fundamentale ale vieții ca un continuum, stabilind în același timp bazele unei structuri teologice. Liderul profet face acest lucru separând lumea în două dimensiuni - dimensiunea sacră și dimensiunea profană - o separare care rămâne la baza delimitărilor teritoriale și temporale. $\mathrm{Cu}$ aceste orizonturi contrastante, liderul - profet folosește ritualul pentru a construi spațiul sacru, face distincția între haos și ordine și reorientează omul către o idee de „centru”. Delimitarea spaţiu - timp a oferit și o bază solidă pentru structurile instituționale ale religiilor organizate, așa cum aceasta a fost și este dictată de regulile ritualului. De pildă, în cazul practicilor vedice timpurii, ritualul a fost folosit în scopul intrării în posesie a unui nou teritoriu, pentru a-l delimita și a-1 face legal valabil prin ceremonia ridicării unui altar (Eliade, 1987, p. 22, 29, 30). Prin urmare, violența interpersonală poate fi validată ca fiind terapeutică numai dacă aceasta este practicată sub condiţiile sacrului, și în spațiul și timpul adecvat. Orice utilizare a violenței interpersonale în afara sacrului este interzisă și respinsă.

\section{Morala culpabilității și a pedepsei}

După cum am observat, conștiința morală a culpabilității și a pedepsei și-au făcut apariția în cadrul psihologiei copilului, de unde au fost translate în societate. Odată cu translarea acestora în spațiul public, societatea a apelat la acest mecanism de culpabilitate - pedeapsă nu numai în cadrul comportamentului zilnic, ci și ori 
de câte societatea a trecut prin momente de criză. Aici, liderul - profet a devenit persoana însărcinată cu autoritatea de a identifica vinovăția și de a aplica pedeapsa adecvată printr-un proces ce a implicat cele patru etape menționate anterior: apariția răului, intervenția liderului - profet ca mediator, diagnosticul cauzei ascunse și aplicarea ispășirii corespunzătoare.

În ceea ce privește identificarea culpabilității care, potrivit lui Burkert (1996, p. 103), a declanșat furia forțelor incontrolabile; furie ce necesită aplicarea ispășirii corespunzătoare, Burkert clarifică în continuare că „vinovăția este în mod obișnuit atribuită încălcării tabuurilor religioase, a neglijării sacrificiilor sau a încălcării regulilor sacre" (Burkert, 1996, p. 113) — toate acestea în avantajul social al liderului - profet. Pe termen lung, fiecare calamitate care și-a făcut apariția, aceasta a oferit liderului - profet o nouă oportunitate de a reîmprospăta și reabilita autoritatea religiei, precum și a propriei autorităţi printr-un model de comportament simbolic prin care liderul - profet a insistat să separe structura și sensul vieții între chestiuni care sunt numinoase și înfiorătoare (Simion, 2017, p. 1-2); oferind totodată şi remediile în scopul stabilităţii sociale.

\section{Religia organizată: violența simbolică, suprastructura teologică și ambivalența structurală}

Odată cu creșterea autorității liderului - profet asupra grupului, atât violența cât și religia devin instituţionalizate în mod progresiv. Prin repetitivitate, practica sacrificării țapului ispășitor a condus la crearea unor ritualuri religioase complexe care au făcut distincții clare între beneficiile violenței controlate și pericolele violenței necontrolate. Culpabilitatea și pedeapsa, care au derivat din psihologia copilului, au condus la dezvoltarea unor precepte sacre care au făcut tranziția de la tabuuri la legi inteligibile. Separarea activității umane între sacru și profan a dus la dezvoltarea unor narațiuni sacre care au definit sensul vieții prin încercări de a da răspuns motivelor fundamentale ale existenței umane. Mai mult, religia primitivă și-a atins maturitatea și s-a consolidat prin elaborarea unor narațiuni sacre, prin impunerea în comportamentul public și privat a unor reguli care să se sincronizeze cu narațiunile corespunzătoare și prin comportamentul stilizat al ritualului care a avansat interesele liderului - profet de a oferi stabilitate socială și de a-și maximiza autoritatea morală.

De asemenea, este important de menționat că tranziția de la religia organizată primitivă la cea avansată nu a făcut decât să extindă complexitatea doctrinelor, a eticii și a ritualurilor; nu le-a reinventat. Narațiunea religioasă a evoluat de la un mit primitiv la texte sacre complexe și suprastructuri teologice. Mitul avansat nu a făcut decât să modifice sau să înlocuiască mitul primitiv; nu a inventat mitul sau ideea de mit în sine. $\mathrm{Cu}$ alte cuvinte, dacă demarcația dintre sacru și profan a religiei primitive a creat naraţiunea sensului religios, în religia avansată, sensul religios a fost înfrumusețat și mai mult prin producția de scripturi care au devenit surse pentru validările dogmatice ale adevărului suprem. 
Conceptele de culpabilitate și pedeapsă din religia primitivă au evoluat către instituirea unor standarde flexibile de comportament colectiv, cum ar fi canoanele, sau au evoluat în legi foarte stricte ce au favorizat fie liderul - profet fie monarhul politic. Fenomenele de sacrificiu și țap ispășitor au fost din ce în ce mai virtualizate și transferate în spațiul simbolic, unde violența a redus semnificativ durerea fizică. Mai mult, durerea fizică a devenit o chestiune de alegere personală şi a fost practicată cu scop devoțional. Aceasta a evoluat în forme de asceză severă (așa cum se poate vedea în hinduism, în budism și creștinism) sub forma unor pedepse autoprovocate (așa cum se vede în cazul îngenuncherilor prelungite, a înfometării, a auto-flagelării, a durerii provocate), cât și sub alte forme de austerități devoționale ce pot fi regăsite în practicile spirituale ale religiilor contemporane.

În ceea ce privește violența, un progres extrem de semnificativ al tranziției de la starea primitivă la cea avansată a religiei organizate este instituționalizarea ambivalenței interpretative de către liderul - profet. Ancorată în eficacitatea sacrificiului, puterea terapeutică a violenței controlate este folosită în circumstanțe determinate exclusiv de către liderul - profet. În acest sens, liderul - profet și-a creat propria flexibilitate de a folosi, cu sau fără prevaricațiune, instrumentele păcii sau instrumentele violenței. În momentele de criză socială, liderul - profet a selectat nu numai textele și narațiunile sacre corespunzătoare cu scopul de a justifica pacea sau violența, ci a selectat și ritualurile adecvate cu scopul aplicării unei soluții simbolice ce au sugerat reacții comportamentale pașnice sau coercitive faţă de adversari. În Anexă, oferim o diagramă orientativă cu scopul ilustrării conceptelor de bază, a ritualurilor, a legilor și a textelor sacre din cinci religii contemporane pentru a demonstra faptul că ambivalența față de violenţă este o parte intrinsecă a religiei organizate. Mai mult, existența acestor resurse mai demonstrează și faptul că religiile contemporane sunt echipate cu instrumente strategice precum doctrine, reguli etice, ritualuri și texte sacre pentru a impune pacea sau pentru a folosi violența atunci când acestea gestionează un conflict - totul în scopul maximizării șanselor de supraviețuire și în obținerea avantajelor competitive.

\section{Concluzie}

În concluzia acestor corelații dintre violența interpersonală și progresul religiei organizate, este important să amintim următoarele: În primul rând, în acest articol am încercat să demonstrăm faptul că violența interpersonală este un fenomen ce pare că a influențat progresul religiei organizate mult mai mult decât suntem dispuși să acceptăm. Prin ritualuri de tranziție, prin mecanismul triangulării (prin care autoritatea părintelui asupra conflictului interpersonal al copiilor a fost transferată liderului - profet asupra conflictului colectiv al adulților), prin mecanismul violenței mimetice (dezvăluit de psihologia copilului), împreună cu rezolvarea acestuia în fenomenul de țap ispăşitor, prin dezvoltarea conștiinței morale a culpabilității, tiparul violenței și al soluționării acesteia a fost transferat de la particular la general ca un continuum. În al doilea rând, în acest articol am încercat să demonstrăm că 
religia nu este inerent violentă și că utilizarea violenței limitate de către religie este exclusiv terapeutică pentru grup și este concepută pentru asigurarea supraviețuirii acestuia. În al treilea rând, an încercat să demonstrăm că religia avansată a făcut progrese semnificative în transferarea sensului violenței de la real la simbolic. A făcut acest lucru prin virtualizarea țapului ispăşitor și printr-o schimbare a hermeneuticii violenței care a abandonat confruntarea fizică în favoarea războiului simbolic și spiritual. În al patrulea rând, am mai încercat să demonstrăm şi faptul că religia organizată și-a construit propriile instrumente strategice pentru a impune pacea în mod direct (ca pacifism) și indirect (prin justificări limitate ale violenței) prin doctrine, texte sacre, principii etice și ritualuri.

\section{Referințe bibliografice:}

1. Burkert, W., 1979. Structure and history in Greek mythology and ritual, University of California Press, Berkeley, LA.

2. Burkert, W., 1986. Homo Necans: The anthropology of ancient Greek sacrificial ritual and myth, University of California Press, Berkeley, LA.

3. Burkert, W., 1996. Creation of the sacred: Tracks of biology in early religions, Harvard University Press, Cambridge, MA.

4. Denzler, M. \& Förster, J., Liberman, N., 2009. 'How goal-fulfillment decreases aggression', Journal of Experimental Social Psychology 45(2009), 90-100. https://doi. org/10.1016/j.jesp.2008.08.021

5. Dollard, J., Doob, L.W., Miller, N.E., Mowrer, O.H. \& Sears, R.R., 1939. Frustration and aggression, Yale University Press, New Haven, CT.

6. Douglas, T., 1995. Scapegoats: Transferring the blame, Routledge, New York.

7. Durkheim, E., 1969. The elementary forms of the religious life, The Free Press, New York.

8. Eliade, M., 1974. The myth of eternal return or, cosmos and history, Princeton University Press, Princeton, NJ.

9. Eliade, M., 1987. The sacred and the profane: The nature of religion, A Harvest Book Harcourt Brace \& World, Inc., New York.

10. Fisher, M.P., 2008. Living religions, 7th edn., Pearson Prentice Hall, Upper Saddle River, NJ.

11. Frazer, J., 1996. The golden bough, Penguin Books, New York.

12. Freud, S., 1998. Totem and taboo, Dover Publications, New York.

13. Girard, R., 1977. 'Violence and representation in the mythical text', Comparative Literature 92(5), 922-944. https://doi.org/10.2307/2906884

14. Girard, R., 1979. Violence and the sacred, The John Hopkins University Press, Baltimore, MD.

15. Girard, R., 1986. The scapegoat, The Johns Hopkins University Press, Baltimore, MD. 
16. Girard, R., 1987. Things hidden since the foundation of the world, Stanford University Press, Stanford, CA.

17. Girard, R., 1996. The Girard reader, ed. J.G. Williams, Crossroad Press, New York.

18 Girard, R., 2001. I see Satan fall like lightening, Orbis Books, Maryknoll, NY.

19. Hubert, H. \& Mauss, M., 1981. Sacrifice: Its nature and functions, University of Chicago Press, Chicago, IL.

20. Juergensmeyer, M., Kitts, M. \& Jerryson, M., 2013. The oxford handbook of religion and violence, Oxford University Press, Oxford.

21. Lienhardt, G., 2003. Divinity and experience: The religion of the Dinka, Oxford University Press, New York.

22. Lorenz, K., 1966. On aggression, Harcourt Brace \& World, New York.

23. Moosajee, M., 2003. 'Violence - A noxious cocktail of genes and the environment', Journal of the Royal Society of Medicine 96(5), 211-214.

24. Nayak, A., 2000. Religions et violences: Sources et interactions. Symposium, Editions Universitaires, Fribourg.

25. Pals, D.L., 2006. Eight theories of religion, 2nd edn., Oxford University Press, New York.

26. Simion, M.G., 2012. Religion in political conflict: a constructivist theoretical model for public policy analysis, design, and implementation, PHD thesis, Northeastern University, Boston.

27. Simion, M.G., 2017. 'The ambivalence of ritual in violence: Orthodox Christian perspectives', HTS Teologiese Studies/Theological Studies 73(3), a4526. https://doi. org/10.4102/hts.v73i3.4526

28. Sir Pritchard, E.E.E., 1956. Nuer religion, Oxford University Press, New York.

29. Sparks, J.B. , 2013. Time chart of world religion: A histomap of faith through the ages, Sterling Metro Books, New York.

30. Turner, V.W., 1981. The drums of affliction: A study of religious process among the Ndembu of Zambia, Cornell University Press, Ithaca, NY.

31. Weber, M., 1977. On charisma and institution building, Chicago University Press, Chicago, IL.

32. Weber, M., 1991. The sociology of religion, Beacon Press, Boston, MA.

33. Westbrook, R. \& Lewis, T.J., 2008. 'Who led the scapegoat in Leviticus 16:21?', Journal of Biblical Literature 127(3), 417-422. https://doi.org/10.2307/25610131 


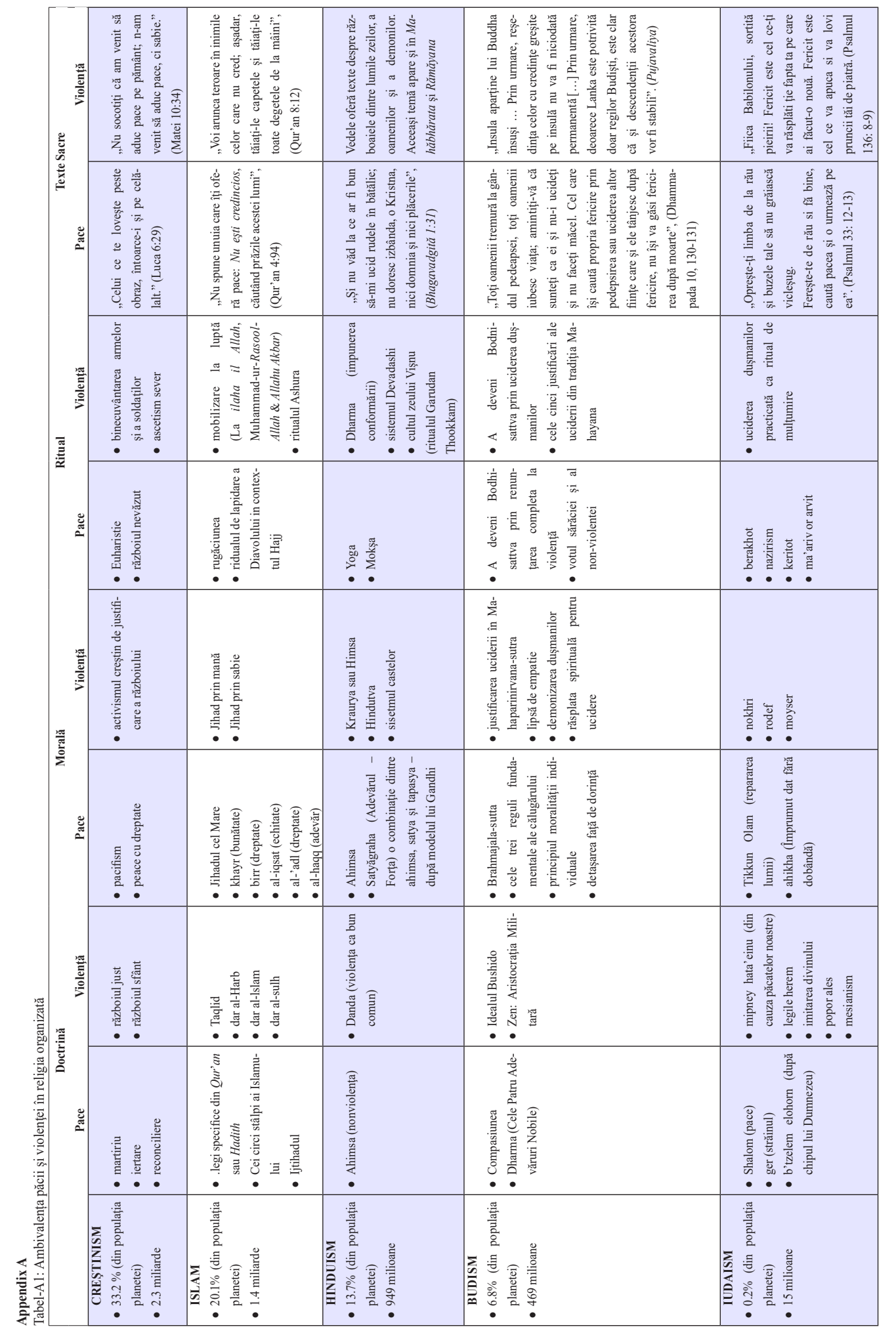

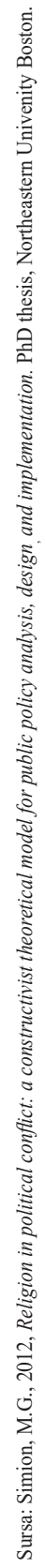

